\title{
Permasalahan Sumberdaya Air Pulau Karang Sangat Kecil (Studi Kasus di Pulau Pramuka, Kabupaten Kepulauan Seribu, DKI Jakarta) Ahmad Cahyadi ${ }^{1}$
}

\author{
${ }^{1}$ Magister Perencanaan Pengelolaan Pesisir dan Daerah Aliran Sungai (MPPDAS) Fakultas Geografi \\ Universitas Gadjah Mada Yogyakarta \\ 1ahmadcahyadi@geo.ugm.ac.id
}

\begin{abstract}
ABSTRAK
Pulau Pramuka sebagai ibukota Kabupaten Kepulauan Seribu, Provinsi DKI Jakarta terus mengalami perkembangan dalam pemanfaatan dan penglolaannya untuk mendukung fungsinya sebagai ibukota. Namun demikian, pembangunan dan pengembangan wilayah pulau karang sangat kecil (very small cay) hendaknya memperhatikan karakteristik sumberdaya airnya yang unik. Penelitian ini bertujuan untuk melakukan kajian tentang permasalahan sumberdaya air yang terdapat di Pulau Pramuka Kabupaten kepulauan Seribu, Provinsi DKI Jakarta. Metode yang digunakan dalam penelitian ini meliputi indepth interview dengan masyarakat Pulau Pramuka, survei lapangan berupa deskripsi kondisi lingkungan dan sanitasi, dan pengukuran kedalaman muka airtanah serta pengambilan sampel material tanah untuk analisis kerentanan airtanah (Groundwater Vulnerability) menggunakan metode DRASTIC, serta analisis kandungan klorida dalam airtanah dan pengklasifikasiannya menggunakan klasifikasi Stuyfzand untuk memetakan sebaran intrusi air laut. Hasil analisis menunjukkan bahwa permasalahan sumberdaya air di Pulau Pramuka adalah intrusi air laut, kerentanan airtanah yang tinggi, pengelolaan sanitasi yang buruk, kuantitas sumberdaya air yang terbatas serta semakin sedikitnya imbuhan airtanah akibat perubahan penggunaan lahan.
\end{abstract}

Kata Kunci: Sumberdaya Air, Pulau Karang Sangat Kecil, Pulau Pramuka

\section{PENGANTAR}

Jumlah pulau di Indonesia lebih dari 17.000 pulau (Hehanusa dan Bhakti, 2004), di mana sebagaian besar dari pulau-pulau tersebut merupakan pulau kecil dan pulau sangat kecil (marfai dkk, 2012). Falkland (1991) mejelaskan bahwa pulau kecil adalah pulau dengan luas kurang dari $2.000 \mathrm{~km}^{2}$, sedangkan pulau sangat kecil adalah pulau dengan luas kurang dari $100 \mathrm{~km}^{2}$ atau pulau yang memiliki lebar kurang dari $3 \mathrm{~km}$. Luas pulau yang tidak terlalu besar kemudian menyebabkan pulau-pulau kecil memiliki karakteristik yang unik terkait dengan bencana, sumberdaya dan dinamika sosial dan fisiknya (Marfai dkk, 2012).

Kepulauan seribu merupakan salah satu gugusan kepulauan dengan pulau-pulau sangat kecil. Sejak akhir Tahun 2003 gugusan kepulauan ini ditetapkan sebagai sebuah kabupaten di Provinsi DKI Jakarta. Ibu kota Kabupaten Kepulauan Seribu terletak di Pulau Pramuka. Status sebagai Ibu Kota Kabupaten menyebabkan Pulau Pramuka teru berkembang, baik dari segi fisik ataupun sosial ekonomi. Pembangunan fisik meliputi pembangunan pelabuhan serta perkembangan bangunan/permukiman serta fasilitas wisata (Afadlal dkk, 2011a). Selain itu, jumlah penduduk-pun bertambah dan diiringi dengan perkembangan sektor jasa dan pariwisata (Afadlal dkk, 2011b). Kondisi demikian tentunya dapat mengancam kelestarian lingkungan Pulau Pramuka apabila tidak direncanakan dan dikelola dengan baik. Hal ini karena Pulau Pramuka sebagai pulau karang sangat kecil memiliki daya dukung lingkungan yang terbatas, tidak terkecuali sumberdaya air tawar. Oleh karena itu, maka makalah ini mencoba untuk menginventarisasi permasalahan terkait sumberdaya air di Pulau Pramuka sebagai suatu masukan dalam perencanaan pembangunan dimasa mendatang.

\section{NERACA AIR PULAU KARANG SANGAT KECIL}

Apabila sebuah pulau kecil dianggap sebagai sebuah sistem hidrologi, maka air yang menjadi masukan bagi air yang ada di dalam sistem, proses yang terjadi terhadap air dan air yang keluar dari sistem hidrologi pulau kecil akan menghasilkan suatu karakteristik neraca air yang unik. Delinom dan Lubis (2007) menyatakan bahwa pulau kecil biasanya memiliki curah hujan yang relatif kecil. Hal ini selain karena luasnya yang sempit juga disebabkan karena curah hujan di pulau kecil biasanya hanya $20 \%$ dari curah hujan mainland terdekat. Kondisi tersebut mengkibatkan jumlah air yang menjadi recharge atau imbuhan airtanah di pula kecil dan sangat kecil sangat sedikit.

Faktor lain yang mempengaruhi neraca air di pulau karang sangat kecil adalah besarnya evapotranspitasi. Proses ini cukup besar pada pulau karang sangat kecil dengan vegetasi yang rapat (Falkland, 1995). Meskipun demikian, proses yang paling banyak menyebabkan terjadinya kehilangan air tawar di wilayah pulau karang sangat kecil adalah proses percampuran airtanah yang berupa lensa (Gambar 1) dengan air laut di sekitarnya (Delinom dan Lubis, 2007). 


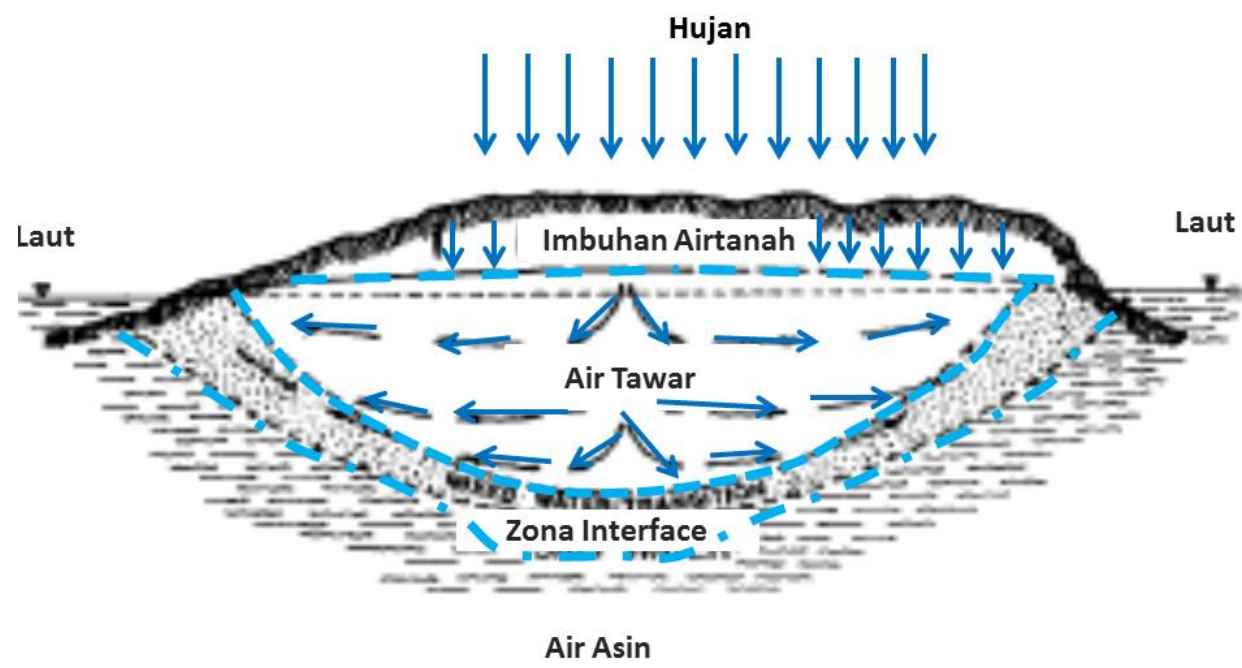

Gambar 1. Lensa Airtanah di Pulau Karang Sangat Kecil/ Very Small Cay (Falkland, 1991)

\section{INTRUSI AIR LAUT}

Intrusi adalah proses penyusupan air asin dari air laut ke dalam airtanah tawar di daratan (Purnama, 2010). Proses ini merupakan salah satu bencana yang mengancam keberlangsungan hidup manusia yang tinggal di pulau sangat kecil (Marfai dkk, 2012). Intrsui dapat terjadi akibat dari pengaruh arus laut yang semakin kuat, sehingga seringkali ditemukan bentuk lensa airtanah yang condong ke salah satu sisi pulau (Falkland, 1991). Selain itu, factor yang palig sering menyebabkan terjadinya intrusi air laut adalah pengambilan/penurapan airtanah yang melebihi hasil aman dari airtanah.

Deteksi intrusi airlaut dapat dilakukan dengan beberapa metode. Metode yang digunakan dalam penelitian ini adalah dengan menganalisis sampel airtanah yang diambil dari Pulau Pramuka (Gambar 2). Sampel yang telah diambil dianalisis kandungan klorida-nya kemudian diklasifikasikan berdasarkan klasifikasi Stuyfzand (Tabel 1).

Tabel 1. Klasifikasi Salinitas Air Berdasarkan Klasifikasi Stuyfzand

\begin{tabular}{|c|c|c|}
\hline Tipe Utama & Kode & Kandungan Cl' (mg/l) \\
\hline Air Tawar & F & $150-300$ \\
\hline Air Tawar-Payau & Fb & $300-1.000$ \\
\hline Air Payau & B & $1.000-10.000$ \\
\hline Air Payau-Asin & Bs & $10.000-20.000$ \\
\hline Air Asin & S & $>20.000$ \\
\hline Air Asin Sangat Tinggi & H & \\
\hline
\end{tabular}

Sumber: Purnama (2010)

Hasil analisis kandungan klorida pada sampel airtanah menunjukkan bahwa sebagian besar dari sampel air memiliki kualitas payau. Hal ini menunjukkan bahwa intrusi air laut telah terjadi di Pulau Pramuka. Hal ini terkait dengan hasil wawancara warga bahwa pada waktu yang lampau airtanah bersifat tawar. Intrusi terdeteksi pada semua sampel airtanah yang diambil pada sisi Barat pulau. Intrusi belum sampai pada sisi Tengah Pulau (Nampak pada sampel 8 dan 9 yang bersifat tawar), sedangkan dibagian Timur terdapat sebagian sampel yang bersifat payau (sampel nomor 7). Kondisi ini disebabkan karena pada Bagian Barat Pulau Pramuka langsung berbatasan dengan laut yang dalam, sedangkan pada sisi Timur Pulau Pramuka masih terdapat rataan terumbu karang (reefflat) yang luas. 


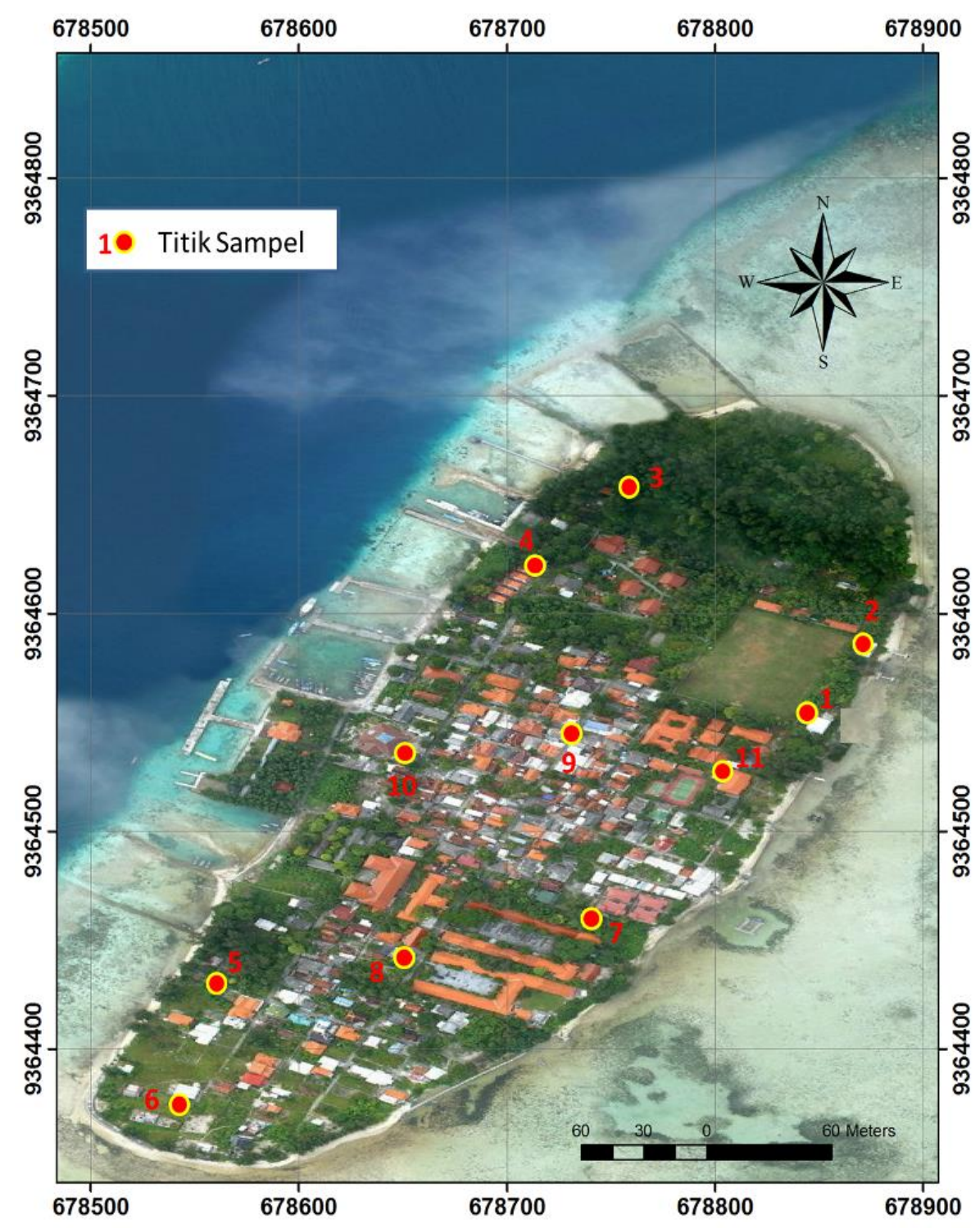

Gambar 2. Lokasi Pengambilan Sampel Airtanah untuk Analisis Sebaran Intrusi

Tabel 2. Hasil Analisis Kadungan Klorida dalam Airtanah di Pulau Pramuka

\begin{tabular}{|c|c|c|}
\hline Nomor Sampel & Kandungan $\mathbf{C l}^{-}(\mathbf{m g} / \mathbf{l})$ & Keterangan Kualitas Air \\
\hline 1 & 28 & Tawar \\
\hline 2 & 60 & Tawar \\
\hline 3 & 344 & Payau \\
\hline 4 & 500 & Payau \\
\hline 5 & 308 & Payau \\
\hline 6 & 402 & Payau \\
\hline 7 & 508 & Payau \\
\hline 8 & 200 & Tawar \\
\hline 9 & 150 & Tawar \\
\hline 10 & 500 & Payau \\
\hline 11 & 150 & Air Tawar-Payau \\
\hline
\end{tabular}

Sumber: Hasil Pengukuran Lapangan 


\section{KERENTANAN AIRTANAH DI PULAU PRAMUKA}

Istilah kerentanan airtanah (groundwater vulnerability) diperkenalkan oleh Margat pada Tahun 1960, seorang ahli hidrologi Perancis (Vrba dan Zaporozec, 1994). Pembuatan peta kerentanan airtanah merupakan upaya yang dilakukan untuk melakukan konservasi dan pencegahan terhadap terjadinya pencemaran airtanah. Airtanah memiliki sifat yang sulit untuk tercemar dibandingkan dengan air permukaan karena terdapat di dalam lapisan tanah, tetapi ketika telah tercemar maka akan sangat sulit dilakukan pemulihan. Kerentanan airtanah diartikan sebagai kemungkinan terjadinya suatu pencemaran atau kontaminasi bahan pencemar pada suatu akuifer di suatu wilayah (Vrba dan Zaporozec, 1994). Pengertian yang lain mengemukakan bahwa kerentanan airtanah adalah ukuran tingkat kemudahan atau tingkat kesulitan suatu polutan dapat mencemari airtanah di suatu wilayah (Harter dan Walker, 2001).

Analisis kerentanan airtanah dalam penelitian ini dilakukan dengan metode DRASTIC. Metode ini menggunakan 7 Parameter, yaitu: Depth to the water table (kedalaman muka airtanah); Recharge (dalam hal ini diperhitungkan sama dengan curah hujan); Aquifer media (media akuifer); Soil media (dalam analisis ini digunakan parameter tekstur tanah); Topography (dalam analisis ini hanya digunakan parameter lereng); Impact of vadose zone (pengaruh zona tidak jenuh); dan Conductivity (konduktuivitas hidraulik). Masing-masing parameter memiliki nilai seperti Nampak pada Tabel 3 sampai dengan Tabel 9.

Tabel 3. Nilai Parameter Kedalaman Airtanah yang Digunakan Dalam Metode DRASTIC

\begin{tabular}{|c|c|c|}
\hline No. & Kedalaman Muka Airtanah (meter) & Nilai \\
\hline 1. & $0-1,5$ & 10 \\
\hline 2. & $>1,5-3$ & 9 \\
\hline 3. & $>3-9$ & 7 \\
\hline 4. & $>9-15$ & 5 \\
\hline 5. & $>15-22$ & 3 \\
\hline 6. & $>22-30$ & 2 \\
\hline 7. & $>30$ & 1 \\
\hline
\end{tabular}

Tabel 4. Nilai Parameter Curah Hujan yang Digunakan Dalam Metode DRASTIC

\begin{tabular}{|c|c|c|}
\hline No. & Curah Hujan (mm/tahun) & Nilai \\
\hline 1. & $0-1.500$ & 2 \\
\hline 2. & $>1.500-2.000$ & 4 \\
\hline 3. & $>2.000-2.500$ & 6 \\
\hline 4. & $>2.500-3.000$ & 8 \\
\hline 5. & $>3.000$ & 10 \\
\hline
\end{tabular}

Tabel 5. Nilai Parameter Media Akuifer yang Digunakan Dalam Metode DRASTIC

\begin{tabular}{|c|c|c|}
\hline No. & Media Akuifer & Nilai \\
\hline 1. & Shale Masif & 2 \\
\hline 2. & Batuan Metamorf/Beku & 3 \\
\hline 3. & Batuan Metamorf/BekuLapuk & 4 \\
\hline 4. & Batu Pasir Tipis, Shale, Batugamping & 6 \\
\hline 5. & Batu PasirMasif & 6 \\
\hline 6. & Batu Gamping Masif & 6 \\
\hline 7. & Pasir dan Kerikil & 8 \\
\hline 8. & Basalt & 9 \\
\hline 9. & Batu gamping Karst & 10 \\
\hline
\end{tabular}


Tabel 6. Nilai Tekstur Tanah yang Digunakan Dalam Metode DRASTIC

\begin{tabular}{|c|c|c|}
\hline No. & Tekstur Tanah & Nilai \\
\hline 1. & Tanah Tipis & 10 \\
\hline 2. & Kerikil & 10 \\
\hline 3. & Pasir & 9 \\
\hline 4. & Shrinking dan atau Agregat Lempung & 7 \\
\hline 5. & Geluh Pasiran (Sandy Loam) & 6 \\
\hline 6. & Geluh (Loam) & 5 \\
\hline 7. & Geluh Lanauan (Silty Loam) & 4 \\
\hline 8. & Geluh Lempungan (Clay Loam) & 3 \\
\hline 9. & Non Shrinking dan non AgregatLempung & 1 \\
\hline
\end{tabular}

Tabel 7. Nilai Kemiringan Lereng yang Digunakan Dalam Metode DRASTIC

\begin{tabular}{|c|c|c|}
\hline No. & Kemiringan Lereng $(\boldsymbol{\%})$ & Nilai \\
\hline 1. & $0-2$ & 10 \\
\hline 2. & $>2-6$ & 9 \\
\hline 3. & $>6-12$ & 5 \\
\hline 4. & $>12-18$ & 3 \\
\hline 5. & $>18$ & 1 \\
\hline
\end{tabular}

Tabel 8. Nilai Material Zona Tak Jenuh yang Digunakan Dalam Metode DRASTIC

\begin{tabular}{|c|c|c|}
\hline No. & Material Zona Tidak Jenuh & Nilai \\
\hline 1. & Lanau/Lempung & 1 \\
\hline 2. & Shale & 3 \\
\hline 3. & Batu Gamping & 6 \\
\hline 4. & Batu Pasir & 6 \\
\hline 5. & Batu Gamping Berlapis (Bedded Limestone) & 6 \\
\hline 6. & Shale danKerikil dengan lanau dan lanau cukup & 6 \\
\hline 7. & Pasir dan Kerikil & 4 \\
\hline 8. & Batuan Metamorf/Beku & 8 \\
\hline 9. & Basalt & 9 \\
\hline 10. & Batu Gamping Karst & 10 \\
\hline
\end{tabular}

Tabel 9. Nilai Konduktivitas Hidraulik yang Digunakan Dalam Metode DRASTIC

\begin{tabular}{|c|c|c|}
\hline No. & Konduktivitas Hidraulik (m/hari) & Nilai \\
\hline 1. & $0-0,86$ & 1 \\
\hline 2. & $>0,86-2,59$ & 2 \\
\hline 3. & $>2,59-6,05$ & 4 \\
\hline 4. & $>6,05-8,64$ & 6 \\
\hline 5. & $>8,64-17,18$ & 8 \\
\hline 6. & $>17,18$ & 10 \\
\hline
\end{tabular}

Hasil dari masing-masing parameter tersebut kemkudian digunakan untuk menentukan nilai kerentanan airtanah di Pulau Pramuka dengan persamaan sebagai berikut: 


\section{Keterangan :}

$\mathrm{D}=$ Depth to the water table (kedalaman muka airtanah);

$\mathrm{R} \quad=$ Recharge (dalam hal ini diperhitungkan sama dengan curah hujan);

A = Aquifer media (media akuifer);

$\mathrm{S} \quad=$ Soil media (dalam analisis ini digunakan parameter tekstur tanah);

$\mathrm{T} \quad=$ Topography (dalam analisis ini hanya digunakan parameter lereng);

I = Impact of vadose zone (pengaruh zona tidak jenuh);

$\mathrm{C}=$ Conductivity (konduktuivitas hidraulik);

$\mathrm{W}=$ Bobot masing-masing parameter (nilai Bobot Lihat Gambar 3.2)

$\mathrm{r} \quad=$ nilai masing-masing parameter

Tabel 10. Bobot Masing-Masing Parameter Dalam Metode DRASTIC

\begin{tabular}{|c|c|c|c|}
\hline No & \multicolumn{2}{|c|}{ Parameter } & Bobot \\
\hline 1 & $\mathrm{D}$ & Kedalaman Muka Airtanah & 5 \\
\hline 2 & $\mathrm{R}$ & Recharge/Hujan & 4 \\
\hline 3 & $\mathrm{~A}$ & Media Akuifer & 3 \\
\hline 4 & $\mathrm{~S}$ & Tanah & 2 \\
\hline 5 & $\mathrm{~T}$ & Topografi & 1 \\
\hline 6 & $\mathrm{I}$ & Pengaruh Zona Tak Jenuh & 3 \\
\hline 7 & $\mathrm{C}$ & Konduktivitas Hidraulik & 3 \\
\hline
\end{tabular}

Nilai yang dihasilken kemudian dimasukkan dalam klsifikasi nilai kerentanan airtanah sesuai dengan Tabel 11 sebagai berikut:

Tabel 11. Klasifikasi Kerentanan Airtanah Dalam Metode DRASTIC

\begin{tabular}{|c|c|c|}
\hline No. & Indeks DRASTIC & Klasifikasi Kerentanan Airtanah \\
\hline 1. & $73-92$ & Tidak rentan \\
\hline 2. & $>92-112$ & Kerentanan rendah \\
\hline 3. & $>112-132$ & Kerentanan sedang \\
\hline 4. & $>132-152$ & Kerentanan tinggi \\
\hline 5. & $>152-172$ & Kerentanan sangat tinggi \\
\hline
\end{tabular}

Tabel 12. Parameter Kerentanan Airtanah Dalam Metode DRASTIC di Pulau Pramuka

\begin{tabular}{|c|c|c|}
\hline Parameter & Kelas Parameter & Nilai \\
\hline Kedalaman Muka Airtanah (D) & $0-1,5 \mathrm{~m}$ & 10 \\
\hline Recharge/Hujan (R) & $>1.500-2.000 \mathrm{~mm} /$ tahun & 8 \\
\hline Media Akuifer (A) & Pasir dan Kerikil & 9 \\
\hline Tanah (S) & Pasir & 10 \\
\hline Topografi (T) & $0-2$ & 4 \\
\hline Pengaruh Zona Tak Jenuh (I) & $>8,64-17,18$ & 8 \\
\hline Konduktivitas Hidraulik (C) & - & 162 \\
\hline
\end{tabular}

Hasil analisis tingkat kerentanan airtanah di Pulau Pramuka seperti ditampakkan pada Tabel 12 menunjukkan bahwa kerentanan airtanah di Pulau Pramuka sangat tinggi. Kondisi ini sangat dipengaruhi oleh semua parameter dalam metode DRASTIC yang menunjukkan kelas yang tinggi pada setiap parameter kecuali recharge dan pengaruh zona tidak jenuh. Oleh karena itu, diperlukan upaya-upaya untuk melakukan pencegahan terhadap potensi pencemaran yang terjadi khusunya pencemaran yang berasal dari limbah rumah tangga. 
Pengelolaan sampah di Pulau Pramukla saat ini dilakukan dengan mengumpulkan sampah di sisi Utara Pulau dan kemudian dibakar. Kondisi ini menyebabkan kondisi airtanah (sampel 2) berbau, berasa dan memiliki warna yang hitam pekat. Selain itu, limbah cair dari kegiatan rumah tangga serta dari kegiatan MCK belum dikelola dengan menggunakan IPAL dan hanya dibuang langsung ke lingkungan. Kondisi ini nampak dari banyaknya masyarakat yang membuat septictank dengan semen namun dengan bagian bawah yang tidak tertutup, sedangkan limbah domestik cair dibuang melalui selokan langsung ke laut atau di sekitar rumah. Hal ini kemudian akan menyebabkan pencemaran airtanah yang lebih parah.

\section{PENGGUNAAN LAHAN DAN KAITANNYA DENGAN NERACA AIR PULAU PRAMUKA}

Penggunaan lahan memiliki peranan yang penting dalam neraca air pulau karang sangat kecil. Cahyadi dkk (2011) dan Cahyadi dkk (2012) menjelaskan bahwa banyaknya penggunaan lahan terbangun akan menyebabkan sedikitnya retensi airtanah, sedikitnya air yang menjadi imbuhan bagi airtanah serta menyebabkan banyaknya air hujan yang berubah menjadi limpasan. Penggunaan lahan berupa asrama siswa dan guru dengan jumlah penghuni yang banyak menyebabkan terjadinya intrusi air laut. Hal ini namp[ak dari hasil analisis terhadap kandungan klorida pada sampel nomor 7. Meskipun terletak di sisi Timur Pulau, tetapi airtanah bersifat payau. Perubahan penggunaan lahan di Pulau Pramuka yang cukup intensif untuk mendukung fungsinya sebagai ibukota administratif dan lokasi wisata hendaknya ditata dan direncanakan ulang agar damapk dikemudian hari berupa semakin sedikitnya airtanah dapat dihindarkan.

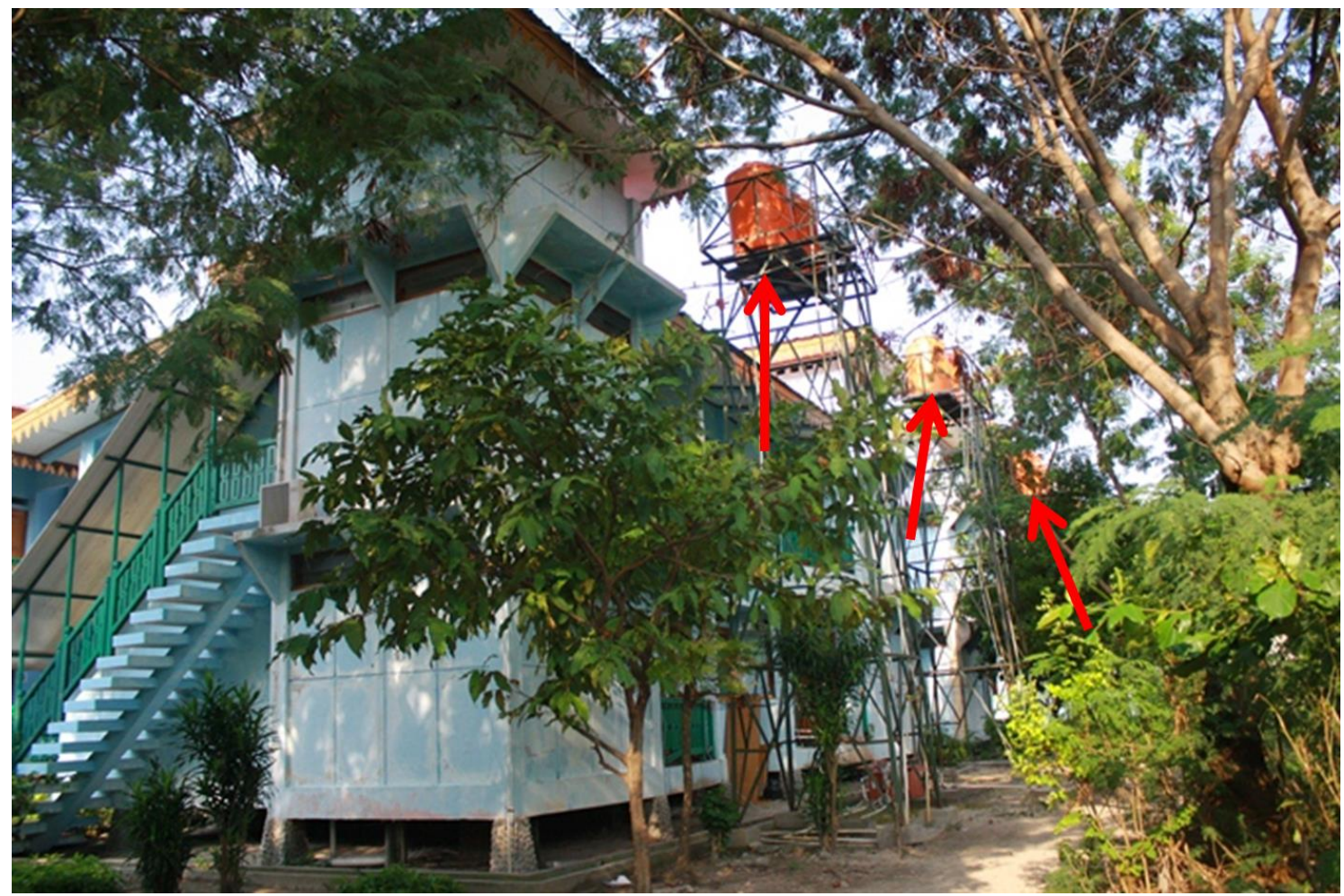

Gambar 3. Ekstraksi Airtanah yang Berlebihan pada Penggunaan Lahan Asrama Telah Menyebabkan

Terjadinya Intrusi Air Laut (Tanda Merah Menunjukkan Tampungan Air yang Digunakan)

\section{PERTAMBAHAN JUMLAH PENDUDUK DAN KAITANNYA DENGAN KEBUTUHAN AIR PULAU PRAMUKA}

Faktor lain yang sangat berpengaruh terhadap sumberdaya air di Pulau Pramuka adalah jumlah penduduk yang semakin bertambah (Gambar 4). Pertumbuhan penduduk di Pulau Pramuka 2,51\% per tahun, sedangkan jumlah penduduk Pulau Pramuka Tahun 2008 adalah sebanyak 1.039 orang. Jumlah penduduk yang semakin bertambah akan menyebabkan jumlah kebutuhan air semakin meningkat, sedangkan ketersediaan cenderung tetap, bahkan terus berkurang. Selain itu ekstraksi airtanah akan semakin banyak sehingga menyebabkan terjadinya intrusi air laut yang semakin luas sebaran spasialnya. Hal lain yang mungkin terjadi sebagai dampak pertambahan penduduk adalah jumlah sampah dan limbah yang dihasilkan akan semakin banyak sehingga potensi pencemaran sumberdaya air akan semakin tinggi. 


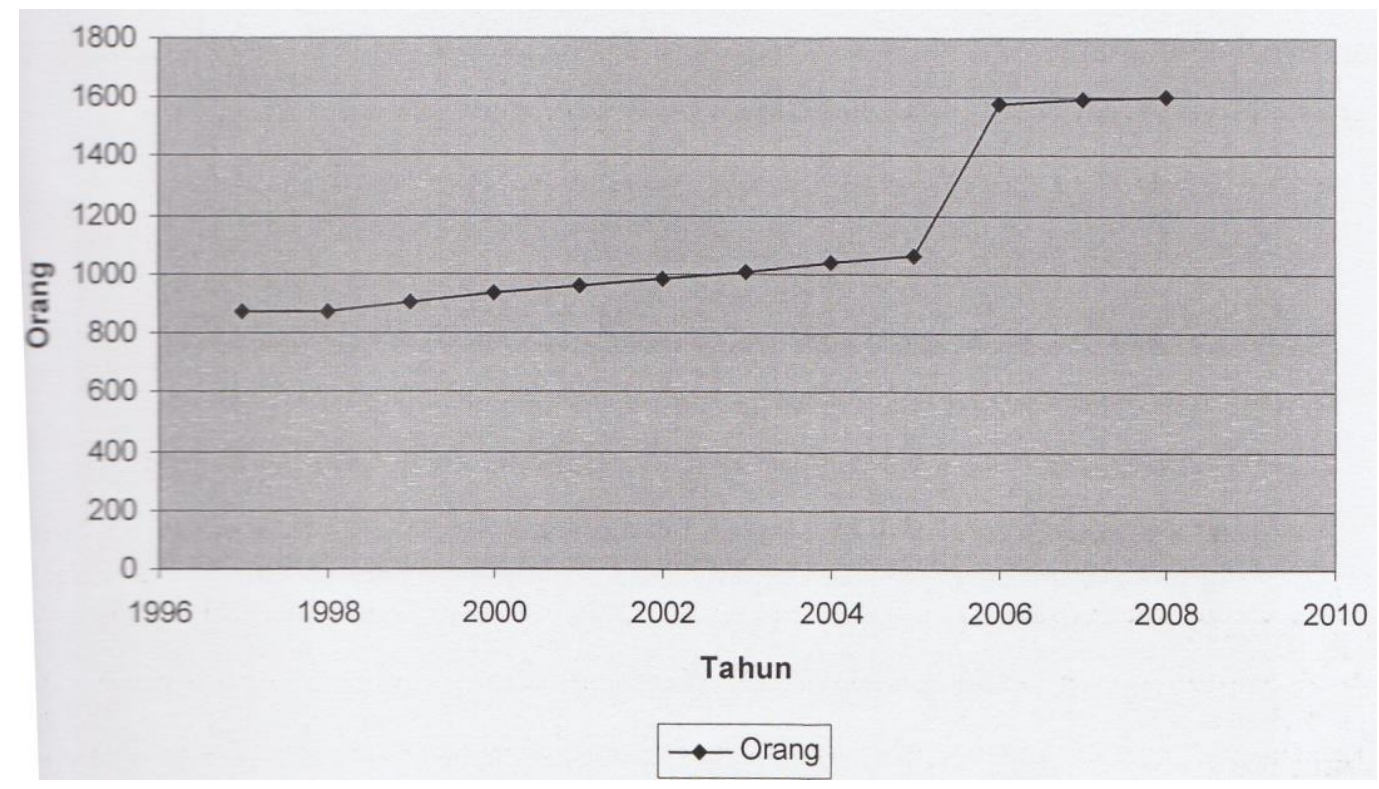

Gambar 4. Grafik Pertumbuhan Penduduk di Pulau Pramuka (Afadlal dkk, 2011a)

\section{PENGAKUAN}

Penelitian ini merupakan sebagian kecil dari tesis penulis pada Magister Perencanaan Pengelolaan Pesisir dan Daerah Aliran Sungai (MPPDAS) Fakultas Geografi Universitas Gadjah Mada Yogyakarta.

\section{REFERENSI}

Afadlal; Wijonarko, S.; Meifina; Septi, A.; Ongkosongo, A.E. dam Ongkosongo, O.S.R., 2011a, Kondisi Lingkungan Sosial, Ekonomi dan Budaya di Pulau Pramuka, dalam Ongkosongo, O.S.R.; Wijonarko, S. Dan Afadlal, 2011, Rona Lingkungan Pulau Pramuka, Jakarta: Lembaga Ilmu Pengetahuan Indonesia (LIPI), Pusat Penelitian Oseanografi, Balai Dinamika Laut, Kolompok Penelitian Geologi Laut.

Afadlal; Wijonarko, S.; Meifina; Septi, A.; Ongkosongo, A.E. dam Ongkosongo, O.S.R., 2011b, Tanggapan Penduduk Terhadap Rencana Revitalisasi Pulau Pramuka, dalam Ongkosongo, O.S.R.; Wijonarko, S. Dan Afadlal, 2011, Rona Lingkungan Pulau Pramuka, Jakarta: Lembaga Ilmu Pengetahuan Indonesia (LIPI), Pusat Penelitian Oseanografi, Balai Dinamika Laut, Kolompok Penelitian Geologi Laut.

Cahyadi, A.; Priadmodjo, A. dan Yananto, A., 2011, Criticizing The Conventional Paradigm of Urban Drainage, Makalah dalam International Graduate Student Conference on Indonesia (IGSCI), Tanggal 8-9 November 2011, Sekolah Pasca Sarjana Universitas Gadjah Mada Yogyakarta.

Cahyadi, A.; Yananto, A.; Wijaya, M.S. dan Nugraha, H., 2012, Analisis Pengaruh Perubahan Penggunaan Lahan Terhadap Retensi Potensial Air oleh Tanah pada Kejadian Hujan Sesaat (Studi Kasus Perubahan Penggunaan Lahan di DAS Garang Jawa Tengah), Prosiding Seminar Nasional "Peran Geoinformatika dalam Pengelolaan Sumber Daya Alam Indonesia”, 30 Juni 2012, Jurusan Teknik Informatika UPN Veteran Yogyakarta.

Delinom, R.M. dan Lubis, R.F., 2007, Air Tanah di Pesisir dan Pulau-Pulau Kecil, dalam Delinom, R.M., 2007, Sumber Daya Air di Wilayah Pesisir dan Pulau-Pulau Kecil di Indonesia, Bandung: Lembaga Ilmu Pengetahuan Indonesia. Pusat Penelitian Geoteknologi.

Falkland, A., 1991, Hydrology and Water Resources of Small Island: A Practical Guide, Paris: Unesco.

Falkland, A., 1995, Water Resources Assesment Development and Management of Small Coral Island, Makalah dalam Training Workshop on Water Resources Assesment and Development in Small Islands and Coastal Zone, Pulau Pari dan Bandung Indonesia, Januari 1995.

Harter, T. dan Walker, L. G., 2001, Assessing Vulnerability of Groundwater, California: California Department of Health Services.

Hehanusa, P.E. dan Bhakti, H., 2004, Sumber Daya Air di Pulau Kecil, Bandung: Lembaga Ilmu Pengetahuan Indonesia, Pusat Penelitian Geoteknologi.

Marfai, M.A.; Cahyadi, A. dan Poerbandono, R., 2012, Identifikasi Bencana Pesisir dan Kerusakan Lingkungan Di Pulau Pramuka, Provinsi DKI Jakarta. Laporan Penelitian. Magister Pengelolaan Pesisir dan Daerah Aliran Sungai (MPPDAS), Fakultas Geografi, Universitas Gadjah Mada.

Purnama, S., 2010, Hidrologi Air Tanah, Yogyakarta: Kanisius.

Vrba, J. dan Zoporozec, A., 1994, Guidebook on Mapping Groundwater Vulnerability, Hannover: International Association of Hydrogeologist. 